\title{
Mansikan kukintageenien identifiointi
}

\author{
Timo Hytönen ${ }^{1)}$, Katriina Mouhu ${ }^{1,2)}$, Marja Rantanen ${ }^{1,2)}$, Paula Elomaa ${ }^{1)}$ \\ ${ }^{1)}$ Soveltavan biologian laitos, PL27,00014 Helsingin yliopisto, timo.hytonen@helsinki.fi \\ ${ }^{2)}$ Finnish Graduate School in Plant Biology, PL56, 00014 Helsingin yliopisto
}

\section{Tiivistelmä}

Tutkimme mansikan kukinnan säätelyä käyttämällä mallikasvina ahomansikkaa (Fragaria vesca L.). Ahomansikka on ehdollinen lyhyenpäivänkasvi, jonka päivänpituusvaste riippuu voimakkaasti lämpötilasta. Yli $15^{\circ} \mathrm{C}$ :een lämpötilassa kukintainduktio tapahtuu vain lyhyessä päivänpituudessa. Sen sijaan alhaisemmassa lämpötilassa kukinta indusoituu päivänpituudesta riippumatta, ja yli $21{ }^{\circ} \mathrm{C}$ :een lämpötilassa kukintainduktio estyy. Luonnossa kukka-aiheet muodostuvat syksyllä ja kukinta ajoittuu lyhyelle jaksolle seuraavana kesänä. Tämän jaksottaissatoisen genotyypin lisäksi ahomansikasta tunnetaan myös jatkuvasatoisia lajikkeita, joita on kutsuttu myös kuukausimansikoiksi. Risteytyskokeilla on osoitettu, että yhden tuntemattoman geenin (SEASONAL FLOWERING LOCUS, SFL) resessiiviset alleelit saavat aikaan jatkuvasatoisuuden. Sen sijaan $S F L: n$ dominoivat alleelit estävät kukintainduktion, ja kukintainduktio voi tapahtua vasta kun päivänpituuden lyheneminen tai alhainen lämpötila kumoavat $S F L: n$ vaikutuksen.

Mansikan kukinnan säätelyä ei ole tutkittu molekyylitasolla, vaikka sadon aikaisuus, satokauden pituus ja sadon määrä ovat riippuvaisia kukinnasta. Tärkeimpien kukintamekanismien selvittämisessä SFL:n löytäminen sekä jatkuvasatoisten ja jaksottaissatoisten genotyyppien molekyylitason vertailu ovat keskeisiä tutkimuskohteita. Tällä tutkimuksella on myös laajempi merkitys monivuotisten kasvien kasvukierron säätelyn ymmärtämiselle.

Olemme identifioineet mansikalta lähes 70 kukinnan kandidaattigeeniä, jotka sekvenssihomologian perusteella vastaavat mallikasvi lituruohon kukintageenejä kaikilta tunnetuilta kukinnan säätelyreiteiltä (päivänpituus-, vernalisaatio-, autonominen ja gibberelliinireitti). Lisäksi olemme löytäneet homologit ns. kukinnan integraattorigeeneille, FLOWERING LOCUS T (FT) ja SUPPRESSOR OF OVEREXPRESSION OF CONSTANS1 (SOC1) sekä kukkameristeemin identiteettigeeneille FRUITFULL (FUL) ja LEAFY (LFY). Olemme tutkineet 25 geenin ilmenemistä jatkuvasatoisen ja jaksottaissatoisen genotyypin lehdissä ja kärkikasvupisteessä. Tulokset osoittavat, että $F U L: n$ ja $L F Y: n$ ilmeneminen voimistuu jatkuvasatoisen ahomansikan kärkikasvupisteessä kukintainduktion jälkeen. FUL ilmenee voimakkaasti myös jatkuvasatoisen ahomansikan lehdissä kukintaan indusoivissa olosuhteissa.

Tutkimuksemme osoittaa, että mansikan genomista löytyvät homologit suurelle osalle lituruohon kukintageenejä kaikilta tunnetuilta säätelyreiteiltä. Keskeisimpien geenien toiminnan testaus on välttämätöntä mansikan kukinnan säätelyn ymmärtämiseksi, sillä yksittäiset geenit ja säätelyreitit voivat toimia eri tavoin mansikalla ja lituruoholla. Kukinnan kandidaattigeenien kartoittaminen laajassa mittakaavassa sekä löytämämme kukintainduktion merkkigeeni $F U L$ tehostavat mansikan kukintamekanismien tutkimusta, joka tähtää kukintaominaisuuksiltaan parempien mansikkalajikkeiden jalostukseen.

\section{Asiasanat}

Fragaria, geeni, jatkuvasatoinen, kukinta, lämpötila, päivänpituus, Seasonal flowering locus 


\section{Johdanto}

Kukinnan molekyylitason säätelyä on tutkittu paljon mallikasvi lituruoholla (Arabidopsis thaliana (L.) Heynh.). Lituruoholta tunnetaan kuusi kukinnan ajoittumista säätelevää geneettistä reittiä, joista tärkeimmät ovat päivänpituus- vernalisaatio-, gibberelliini- (GA) ja autonominen reitti. Päivänpituus- ja vernalisaatioreitit säätelevät kukintaa ympäristöstä tulevien valo- ja lämpötilasignaalien mukaan ja GA- ja autonominen reitti reagoivat kasvin sisäisiin signaaleihin (Boss ym. 2004). Kaksi ns. kukinnan integraattorigeeniä ( $F T$, $S O C 1)$ yhdistävät eri säätelyreiteiltä tulevat signaalit aktivoiden kukka-aiheiden muodostuksen $A P 1 / F U L j a$ $L F Y$-geenien kautta (Ausin ym. 2005).

Päivänpituusreitillä keskeinen säätelijä on CO (CONSTANS), joka "mittaa" päivittäisen valojakson pituutta. Kukintainduktio tapahtuu pitkässä päivässä, kun CO:n aktivoima FT -proteiini kulkee johtosolukkoa pitkin kärkikasvupisteeseen (Turck ym. 2008). Osa lituruohogenotyypeistä vaatii vernalisaation eli pitkäaikaisen kylmäkäsittelyn ennen kukintaa. Näillä genotyypeillä aktiivinen FLC estää $F T$ :n ja $S O C 1$ :n ilmenemisen. Vasta kylmäkäsittely hiljentää $F L C:$ n, jolloin kukinta voi indusoitua normaalisti päivänpituusreitin kautta (Searle ym. 2006). Myös autonominen reitti aktivoi kukintaa hiljentämällä $F L C: n$ ilmenemistä genotyypeillä, jotka eivät vaadi vernalisaatiota. Gibberelliini aktivoi kukintaa SOC1:n ja LFY:n kautta erityisesti lyhyenpäivän oloissa (Boss ym. 2004).

Mansikka on ehdollinen lyhyenpäivänkasvi, joka indusoituu kukintaan päivänpituuden laskiessa alle kriittisen rajan tai päivänpituudesta riippumatta lämpötilan ollessa alhainen (Guttridge 1985). Mansikasta tunnetaan myös jatkuvasatoisia genotyyppejä, joilla pitkä päivänpituus edistää kukintaa (Hytönen 2009). Tässä tutkimuksessa olemme etsineet kukinnan säätelyn kandidaattigeenejä Rosaceae-heimon mallikasvilta ahomansikalta sekä verranneet valikoitujen geenien ilmenemistä jatkuvasatoisen genotyypin ja villityypin välillä. Työn tavoitteena on hankkia tietoa mansikan kukinnan molekyylitason säätelystä sekä löytää keskeinen kukinnan säätelijä, $S F L$, jonka resessiiviset alleelit saavat aikaan jatkuvasatoisuuden ahomansikalla (Albani ym. 2004).

\section{Aineisto ja menetelmät}

Kaikki kokeet tehtiin ahomansikan siementaimilla. Kokeissa käytetty villityyppi on peräisin Punkaharjulta ja jatkuvasatoinen lajike oli 'Baron Solemacher'. Mansikan sekvenssidatasta etsittiin lituruohon 118 tunnetulle kukintageenille homologisia sekvenssejä tBLASTn algoritmin avulla. Kaikki sekvenssit, joiden samankaltaisuus kukintageenien kanssa oli suurempi kuin 1e-10 analysoitiin uudestaan BLASTx algoritmillä lituruohon proteiinisekvenssejä vastaan. Ne mansikan sekvenssit, jotka BLASTx -haussa palauttivat tBLASTn -haussa käytetyn lituruohon proteiinisekvenssin, hyväksyttiin. Mansikan EST-kirjastojen teko ja sekvensointi sekä RNA:n eristys, cDNA-synteesi ja geeniekspressioanalyysit on kuvattu aiemmin (Mouhu ym. 2009, Hytönen ym. 2009).

\section{Tulokset ja tulosten tarkastelu}

Etsimme mansikan kukintageenejä PCR-monistuksen avulla sekä sekvenssihomologiaan perustuen olemassa olevista sekvenssitietokannoista (National Center for Biotechnology Information, Genome Database for Rosaceae) sekä sekvensoimalla mansikan cDNA-kirjastoja. Löysimme homologit 67 lituruohon kukintageenille, jotka sijoittuvat kaikille tunnetuille kukinnan säätelyreiteille (Boss ym. 2004). Osa geeneistä on esitetty taulukossa 1. Lisäksi monistimme sekvenssihomologiaan perustuen kukinnan integraattorigeenit, SOC1 ja $F T$ sekä kukkameristeemin identiteettigeenin $L F Y$ ahomansikasta. Identifioiduista geeneistä päivänpituusreitille sijoittuvat fotoreseptorigeenit (mm. phyA, cry2) ja keskeisimmät vuorokausikellon geenit (LHY, TOC1) (Thomas 2006). Lisäksi löysimme kaksi läheistä homologia CO:lle, joka on päivänpituusreitin keskeisin säätelijä (Yanovsky \& Kay 2002). Merkittävistä tunnetuista päivänpituusreitin geeneistä puuttui ainoastaan phyB ja GI (Thomas 2006). Alustavien tulosten perusteella molemmat geenit löytyvät kuitenkin pyrosekvensoinnilla tuottamiemme 240000 sekvenssin joukosta (Hytönen, julkaisematon).

Vernalisaatioreitin keskeisimmille geeneille, FLC ja FRI (Johanson ym. 2000, Searle ym. 2006), ei löydetty homologeja mansikan EST sekvensseistä. Ne todennäköisesti puuttuvat mansikalta, sillä niille ei ole löydetty funktionaalisia homologeja Brassicaceae-heimon ulkopuolelta (Searle ym. 2006, Wang ym. 2009). Löysimme kuitenkin homologit suurimmalle osalle $F L C$ :n säätelyyn osallistuvista vernalisaatioreitin ja autonomisen reitin geeneistä. Nämä $F L C$ :n säätelijät vaikuttavat $\mathrm{mm}$. $F L C:$ n kromatiinin metylaatioon (mm. $A T X 1, E L F 8, V I N 3, F L D)$ sekä asetylaatioon (mm. FVE, FLD) ja määräävät siten sen ilmenemistason (Farrona ym. 2008). Tulokset viittaavat siihen, että vastaavat säätelymekanismit ovat olemassa myös mansikalla, 
mutta niillä on eri kohdegeeni(t). Mansikalla ei ole vernalisaatiovaatimusta lukuun ottamatta Altasta PohjoisNorjasta löydettyä ahomansikkagenotyyppiä (Heide \& Sønsteby 2007). Jatkossa tulisi selvittää kromatiinin säätelyyn osallistuvien geenien roolia mansikan kukinnan säätelyssä sekä keskeisimpien säätelijöiden kohdegeenit.

Löysimme myös useita homologeja geeneille, jotka on yhdistetty GA-reittiin lituruoholla (mm. $M Y B 33$ ja $D D F 1)$. Lisäksi olemme aikaisemmassa tutkimuksessa identifioineet useita GA:n biosynteesiin, hajotukseen ja signaalinvälitykseen liittyviä geenejä (Hytönen ym. 2009). Lituruoholla GA edistää kukintaa, mutta mansikalla tehdyissä GA-käsittelykokeissa on saatu päinvastaisia tuloksia (Thompson \& Guttridge 1959). GA:n rooli mansikan kukinnan säätelyssä tulisi varmistaa molekyylitason tutkimuksella.

Taulukko 1. Mansikalta löydettyjä kukinnan kandidaattigeenejä eri kukintareiteiltä. Neljä keskeisintä kukinnan säätelyreittiä on esitetty. Taulukossa on esitetty ne geenit, joiden ilmenemistä tutkittiin. Sarakkeessa "muut" on esitetty kukinnan integraattori- ja identiteettigeenejä.

\begin{tabular}{ccccc}
\hline Valo & Vernalisaatio & Autonominen & Gibberelliini & Muut \\
\hline ELF3 & FRL1 & FVE & GA3ox & SOC1 \\
ZTL & VRN5 & MSI1 & GA2ox & SFY \\
LHY & VRN1 & SVP & & FUL \\
FKF1 & ELF8 & & & \\
CO & LHP1 & & \\
COL4 & VIN3 & & \\
PFT1 & & & \\
HRB1 & & & \\
FYPP3 & & & \\
AP2 & & & \\
\hline
\end{tabular}

Vertasimme 25 kukinnan kandidaattigeenin ilmenemistä jatkuvasatoisen genotyypin ja villityypin kärkikasvupisteissä ja/tai lehdissä real-time-PCR -menetelmällä. Tutkitut geenit on esitetty taulukossa 1. Kokeessa ei löydetty selviä eroja kukinnan säätelyreittien geenien ilmenemisessä jatkuvasatoisen ja lyhytpäivägenotyypin välillä. Ainoastaan kärkikasvupisteen identiteettiä säätelevät geenit, $F U L$ ja $L F Y$, ilmeni selvästi voimakkaammin jatkuvasatoisen ahomansikan kärkikasvupisteessä verrattuna villityyppiin. Näistä $F U L$ ei ilmentynyt lainkaan villityypin kärkikasvupisteessä. Tutkimme näiden geenien ilmenemistä tarkemmin eri kehitysvaiheissa ja havaitsimme, että $F U L$ alkoi ilmetä voimakkaasti 1- ja 2-lehtivaiheiden välillä (Taulukko 2). Myös $L F Y$ aktivoitui jatkuvasatoisella genotyypillä, mutta hiukan myöhemmin. Lituruoholla $L F Y$ ja $F U L$ aktivoituvat kärkikasvupisteessä kukintainduktion tapahduttua ja ne myös aktivoivat toistensa ilmenemistä (Wagner ym. 1999, Parcy 2005). Tässä kokeessa jatkuvasatoisen genotyypin kasvit muodostivat pääjuurakkoon keskimäärin 4,7 lehteä ennen kukintoa. Koska kärkikasvupisteessä on yleensä 3-4 lehtiaihetta, kukintainduktion on pitänyt tapahtua 1-2-lehtivaiheessa eli samaan aikaan kun FUL aktivoitui.

Tulokset osoittavat, että $F U L$ on erinomainen kukinnan merkkigeeni, jonka avulla voidaan osoittaa kukintainduktion tapahtuminen kärkikasvupistenäytteestä. FUL ilmeni myös lehdissä jatkuvasatoisella genotyypillä, ja ilmeneminen oli 11 kertaa voimakkaampaa pitkässä päivässä lyhyeen päivään verrattuna. Alustavat tulokset viittaavat siihen, että $F U L$ aktivoituu myös lehdissä kukintainduktion yhteydessä. Mikäli näin on, kukintainduktion tapahtuminen voidaan todeta PCR-testillä lehtinäytteestä.

Taulukko 2. FUL:n ja $L F Y: n$ ilmenemistaso jatkuvasatoisen ahomansikan kärkikasvupisteissä eri kehitysvaiheissa verrattuna 1-lehtivaiheeseen.

\begin{tabular}{lccc}
\hline & 2 lehteä & 3 lehteä & 4 lehteä \\
\hline$F U L$ & 5,6 & 33,2 & 50,7 \\
$L F Y$ & 1,3 & 2,6 & 4,4 \\
\hline
\end{tabular}




\section{Johtopäätökset}

Olemme identifioineet mansikalta 67 kukinnan kandidaattigeeniä sekvenssihomologiaan perustuen. Tulokset viittaavat siihen, että kaikki mallikasvi lituruoholta tunnetut kukintageenireitit löytyvät myös mansikalta. Geenien ilmenemistä tutkimalla löysimme kukintainduktion merkkigeenin FUL, joka aktivoituu kärkikasvupisteessä kukintainduktion yhteydessä ja ilmenee myös lehdissä kukintaan indusoivissa olosuhteissa. Kukintageenien identifiointi mahdollistaa niiden ilmenemisen ja funktion tutkimisen sekä niiden kartoittamisen mansikan geenikartalle. Hyödynnämme tätä tietoa kukintareittien tutkimisessa ja SFL:n etsimisessä. Kukinnan säätelymekanismien selvittäminen ahomansikalla avaa uusia mahdollisuuksia Rosaceae -heimon kasvien kukintaominaisuuksien jalostukseen.

\section{Kirjallisuus}

Albani, M., Battey, N. H. \& Wilkinson M. J. 2004. The development of ISSR-derived SCAR markers around the SEASONAL FLOWERING LOCUS (SFL) in Fragaria. Theoretical and Applied Genetics 109: 571-579.

Ausín, I., Alonso-Blanco, C. \& Martinez-Zapater, M. 2005. Environmental regulation of flowering. International Journal of Developmental Biology 49: 689-705.

Boss, P. K., Bastow, R.M., Mylne, J.S. \& Dean, C. 2004. Multiple pathways in the decision to flower: enabeling, promoting, and resetting. Plant Cell 16: S18-S31.

Farrona, S., Coupland G. \& Turck, F. 2008. The impact of chromatin regulation on floral transition. Seminars in Cell \& Developmental Biology 19: 560-573.

Guttridge, C.G. 1985. Fragaria $\times$ ananassa. In: Halevy A (ed.). CRC Handbook of Flowering. Vol III. p 1633. CRC Press, Boca Raton.

Heide, O.M. \& Sønsteby, A. 2007. Interactions of temperature and photoperiod in the control of flowering of latitudinal and altitudinal populations of wild strawberry (Fragaria vesca). Physiologia Plantarum 130: 280-289.

Hytönen, T., Elomaa, P., Moritz, T. \& Junttila, O. 2009. Gibberellin mediates daylength controlled differentiation of vegetative meristems in strawberry (Fragaria $\mathrm{x}$ ananassa Duch.). BMC Plant Biology 9: 18 .

Johanson, U., West, J., Lister, C., Michaels, S., Amasino, R. \& Dean, C. 2000. Molecular analysis of FRIGIDA, a major determinant of natural variation in Arabidopsis flowering time. Science 290: 344-347.

Mouhu, K., Hytönen, T. \& Elomaa, P. 2009. Identification of flowering related candidate genes from Fragaria vesca using EST sequencing. Acta Horticulturae 842: 459-462.

Searle, I., He, Y., Turck, F., Vincent, C., Fornara, F., Krober, S., Amasino, R.A. \& Coupland, G. 2006. The transcription factor FLC confers a flowering response to vernalization be repressing meristem competence and systemic signalling in Arabidopsis. Genes \& Development 20: 898-912.

Parcy, M. 2005. Flowering: a time for integration. International Journal of Developmental Biology 49: 585593.

Thomas, B. 2006. Light signals and flowering. Journal of Experimental Botany 57: 3387-3393.

Thompson, P.A. \& Guttridge, C.G. 1959. Effect of gibberellic acid on the initiation of flowers and runners in the strawberry. Nature 184: 72-73.

Turck, F., Fornara, F. \& Coupland, G. 2008. Regulation and identity of florigen: FLOWERING LOCUS T moves central stage. Annual Review in Plant Biology 59: 573-594.

Yanovsky, M.J. \& Kay, S. A. 2002. Molecular basis of seasonal time measurement in Arabidopsis. Nature 419: 308-312.

Wagner, D., Sablowski, R.W.M. \& Meyerowitz, E.M. 1999. Transcriptional activation of APETALA1 by LEAFY. Science 285: 582-584.

Wang, R., Farrona, S., Vincent, C., Joecker, A., Schoof, H., Turck, F., Alonso-Blanco, C., Coupland, G. \& Albani, M. 2009. PEP1 regulates perennial flowering in Arabis alpina. Nature 459: 423-427. 